\title{
Effect of a tourist-ignited wildfire on Nothofagus pumilio forests at Torres del Paine biosphere reserve, Chile (Southern Patagonia)
}

\author{
Efecto de un incendio forestal causado por un turista sobre bosques de Nothofagus pumilio en la \\ reserva de la biosfera Torres del Paine, Chile (Patagonia Austral)
}

\author{
Osvaldo J Vidal a*, Albert Reif ${ }^{\text {a }}$ \\ *Corresponding author: a Albert Ludwigs University Freiburg, Faculty of Forest and Environmental Sciences, Silviculture Institute, \\ Tennenbacherstrasse 4, D 79106 Freiburg, Germany, tel.: (49) (0761) 2033675, fax: (49) (0761) 2033781, \\ osvaldo.vidal@waldbau.uni-freiburg.de
}

\begin{abstract}
SUMMARY
This study describes the impact of a wildfire caused by a tourist at Torres del Paine Biosphere Reserve in 2005, which destroyed approximately 2,000 ha of forests. Changes on biodiversity attributes of Nothofagus pumilio stands including structure, floristic composition and regeneration, are shown. We compared three plot groups having similar site and structure: Cordón Masle burned plots (CMBP); Cordón Masle unburned plots (CMUP), adjacent to the first ones; and Cerro Paine unburned plots (CPUP), outside the fire perimeter. Data was analyzed using univariate (Mann-Whitney) and multivariate (MRPP and ISA) non-parametric analysis. In CMBP, the fire reduced in average $91.7 \%$ of the tree density and $70.9 \%$ of the basal area. In the unburned plots the average of seedling was 23,625 and 22,750 ha-1 in CPUP and CMUP respectively, whereas in burned ones it was only 1,125 ha-1 in CMBP. Canopy layer collapsed and species richness and cover on ground increased significantly in burned plots. The average of exotics increased from 1.5 and 0.6 in CPUP and CMUP respectively to 11.9 in CMBP. Tree mortality, lower regeneration, biological invasion and broken canopy-ground balance in burned stands, are altering the successional pathways of forests, making difficult the forest regeneration and restoration efforts. Based on this information, we propose managers to encourage efforts in fire prevention and to incorporate a database on biodiversity indicators for management plans, in order to know more about the ecological integrity of ecosystems and the impacts provoked by recreation.
\end{abstract}

Key words: biodiversity indicators, biological invasions, fire ecology, forest structure, human disturbances, recreation.

\section{RESUMEN}

Se describe el impacto de un incendio causado por un turista en la reserva de la biosfera Torres del Paine en el 2005 que destruyó aproximadamente 2.000 ha de bosques. Se muestran los cambios ocurridos en atributos de bosques de Nothofagus pumilio incluyendo estructura, regeneración y composición florística. Se comparan tres grupos de parcelas con sitio y estructura semejantes: parcelas incendiadas (CMBP) y parcelas adyacentes no incendiadas (CMUP) del Cordón Masle, y parcelas no incendiadas de Cerro Paine (CPUP), fuera del perímetro del incendio. Se utilizó análisis no paramétricos univariados (Mann-Whitney) y multivariados (MRPP e ISA). En los sitios incendiados, el fuego redujo en promedio el 91,7 \% de la densidad arbórea y el 70,9\% del área basal. El promedio de plántulas fue de 23.625 y 22.750 ha $^{-1}$ en CPUP y CMUP, respectivamente, mientras que en CMBP se redujo a 1.125 ha $^{-1}$. El dosel colapsó y la cobertura y riqueza de especies de sotobosque incrementó significativamente en las parcelas incendiadas. El promedio de exóticas incrementó de 1,5 y 0,7 especies en CPUP y CMUP, respectivamente, hasta 11,9 especies en CMBP. La mortalidad de árboles, escasa regeneración, invasión biológica y el colapso del dosel, están alterando las vías sucesionales de los bosques reduciendo su capacidad de recuperación, dificultando los esfuerzos de restauración. Se propone a los administradores enfatizar esfuerzos en prevención de incendios y desarrollar información sobre indicadores de biodiversidad para los planes de manejo, para así conocer más sobre la integridad ecológica de los ecosistemas y el impacto provocado por la recreación.

Palabras clave: indicadores de biodiversidad, invasiones biológicas, ecología del fuego, perturbaciones humanas, recreación.

\section{INTRODUCTION}

Wildfires affecting Andean Nothofagus spp. forests in southern Patagonia are recognized as catastrophic disturbances, which have strong influences on diversity attributes by changing abruptly the states of dynamics in these ecosystems (Veblen et al. 2008). Beyond their anthropic or natural origin, wildfires produce changes that affect critical components of ecosystem processes like soil properties, vegetation layering patterns and under-story species composition. Fire consequences imply among others, reduction in levels of organic matter on soils (Certini 2005), increment of incoming solar radiation on under-story (Kitzberger et al. 2005), and increased competition because of the income of exotic species in the original ensemble of native ones (Freeman et al. 2007, Donato et al. 2009). Al- 
though Andean Nothofagus spp. forest ecosystems seem to be able to recover after wildfires in absence of ulterior disturbances (Veblen et al. 1996), the relative increment in frequency and severity of wildfires by Euro-Chilean settlers (González et al. 2005) appears to exceed the critical thresholds of resilience in many of these ecosystems, especially in forest dominated by species lacking regenerative strategies after wildfires (Veblen et al. 2008). Thus, a rapid conversion from forests to more open vegetational landscapes like shrub-lands and grassland areas has been carried out during the last century through land use practices, livestock production and, more recently, through exurban population and recreation (Martinic 1985, Veblen and Markgraf 1988, Veblen et al. 2008).

In a context of biological conservation, to know how wildfires affect structure, composition and function of biodiversity at different levels of organization (Noss 1990), and at which levels these disruptions are capable of exceeding resilience thresholds, are becoming key questions for ecological management and restoration purposes (Noss 1990). Such questions are particularly interesting to be addressed in wilderness areas, which are devoted to protecting natural ecosystems and to serving as reference systems of ecological integrity from human impact (Cole and Landres 1996). In Chile wilderness areas are increasingly subjected to anthropogenic pressure arising from recreation and settlement in surrounding areas (Pauchard and Villarroel 2002), thus the generation of detailed information on biodiversity patterns is crucial because this can offer indicators as reference of pristinity or can give light on the ecological significance of potential or real impacts of disruptions (Noss 1990, Cole and Landres 1996). Although generalizations from literature could be useful by providing some guidelines for managers, local studies on this oriented focus seem to be more pertinent because of their assertiveness. This is particularly true for developing ecosystems that present wide range of distribution like the Nothofagus pumilio (Poepp. et Endl.) Krasser forests, which are distributed along the Andean for approximately 2,000 km and present a wide structure and compositional range (Hindelbrand-Vogel et al. 1990). On 17 February 2005, a huge wildfire was ignited at Torres del Paine Biosphere Reserve (Southern Chilean Patagonia), when a careless tourist accidentally flipped his stove on ground vegetation. The fire of approximately four weeks of duration, began on a grassland area but spread rapidly towards other communities, destroying valuable habitats including steppes, shrub-lands and forests along 17,000 ha inside the reserve and adjacent private lands, including approx. 2,000 ha of N. pumilio forests (Domínguez et al. 2006, Navarro-Cerrillo et al. 2008). Although the effects of this wildfire event have been evaluated from a landscape perspective using remote sensor data to estimate fire perimeter and affected surfaces (Navarro-Cerrillo et al. 2008), no studies have been focused on showing the ecological effects of this disturbance from a more biodiversity de- tailed approach. Given the importance of this Biosphere Reserve as a national symbol of Chilean conservation areas, the development of more detailed information on the ecological impacts of this wildfire event appears to be an issue of relative magnitude which could help for conservation and restoration strategies in management plans. Thus, the objectives of the present paper are: 1 ) to develop biodiversity indicators as reference attributes of $N$. pumilio forests in this Biosphere Reserve and 2) to show the effect of fire on three sensitive ecosystem components belonging to these forests: stand structure, regeneration and floristic composition.

\section{METHODS}

Description of the study area. Fieldwork was conducted at Torres del Paine Biosphere Reserve, a protected area located in Última Esperanza province in southern Chilean Patagonia. This 242,000 ha area is dissected by a complex physiography characterized by the Southern Patagonian Ice Fields and the Cordillera Paine, an impressive mountain range that reaches abruptly over 3,000 m. Such contrasting relief determines a variety of climates and an abrupt moisture gradient in west-east direction fluctuating from 1,000 to $300 \mathrm{~mm}$ in annual precipitation (Pisano 1974). The mean temperature reaches $10.8{ }^{\circ} \mathrm{C}$ in summer (January) while in winter season (July) reaches $2{ }^{\circ} \mathrm{C}$. Bioclimatologically the entire area was classified as belonging to the humid-supratemperate belt (Amigo and Ramírez 1998). The soils are from quaternary origin after the glacier retreated approximately 10,000 years ago (Armesto et al. 1992), dominating the Andisol soil types with deposits of volcanic origin (Navarro-Cerrillo et al. 2008). The terrestrial vegetation is diverse, and ranges from arid-steppe communities to mixed Nothofagus spp. forests in the moistest places (Pisano 1974). Pure stand forests dominated by $N$. pumilio are located on mountain slopes and valleys, on intermediate elevation levels from 300 to 900 $\mathrm{m}$ altitude and with also intermediate precipitation regimes from 400 to $900 \mathrm{~mm}$ of annual precipitation (Pisano 1974, Armesto et al. 1992). The area was declared a UNESCO Biosphere Reserve in 1978 because of the beauty of its landscapes and its ecosystem representativeness (Pisano 1974, CONAF 2007).

Plot sampling selection. Two locations were selected as study areas to compare the effects of fire on forest components: Cordón Masle mountain range located in the northwest limit of the natural reserve, and Cerro Paine mountain range located approximately $9 \mathrm{~km}$ south-east from the first one. In Cordón Masle the fire perimeter affected extensive forested areas of Nothofagus spp. during the event of 2005 (Navarro-Cerrillo et al. 2008). This area (Cordón Masle) is a middle-elevation mountain range that reaches up to 900 m a.s.l., with mixed stands of $N$. antarctica (G. Forster) Oersted and N. pumilio in lower areas close to watersheds 
and pure stands of $N$. pumilio in elevation from approximately $250 \mathrm{~m}$ up to $800 \mathrm{~m}$. Above this elevation, forests are progressively replaced by Krummholz (Pisano 1974). Forested areas here developed from gentle to steep slopes with south and southeast exposure. Cerro Paine was not located within the fire perimeter of the 2005 event (NavarroCerrillo et al. 2008). This mountain range reaches up to $1,200 \mathrm{~m}$, containing pure forest stands from 300 to $800 \mathrm{~m}$. Similarly to Cordón Masle forested areas, pure N. pumilio forest stands here develop both on gentle and steep slopes with south and south-east exposure.

In February and March 2009 a total of 24 plots in pure $N$. pumilio stands were installed on these two localities according to a stratified sampling, in order to form three comparison groups: 1) Cordón Masle burned plots (CMBP), consisting of a group of eight plots burned on slopes of south and south-west exposure between 381 and $638 \mathrm{~m}$ in elevation; 2) Cordón Masle unburned plots (CMUP), consisting of a group of eight unaffected plots immediately adjacent to burned ones in Cordón Masle, located on slopes of south and south-west exposure, from 430 to $612 \mathrm{~m}$ in elevation. 3) Cerro Paine unburned plots (CPUP), consisting of a group of eight unburned plots outside the fire perimeter in Cerro Paine mountain range and from 356 to $674 \mathrm{~m}$ (figure 1).

The criteria for plot selection were as follows: 1) burned stands were selected having a minimum size to establish a $500 \mathrm{~m}^{2}$ stand plot; 2) after establishing the burned plot, an immediately unburned contiguous forest stand was selected. Here it is assumed that stand structure (e.g. canopy height or trunk diameter) and site conditions (e.g. elevation, slope classes, aspect and soil texture) are similar because of proximity between both stands; 3) a third group of plots in Cerro Paine was installed; 4) unburned plots showed low or no evidence of disturbances by large herbivores (domestic livestock and guanaco (Lama guanicoe)), based on counting of browsed branches inside the plots (Veblen et al. 1989) (appendix 1).

Stands plot structure recordings and regeneration counts. Forest structure was characterized by installing a rectangular 50 x 10 m plot. In each plot from each group, diameters at breast height (DBH) were recorded on all trees having $>5 \mathrm{~cm}$ diameter at $1.3 \mathrm{~m}$ high. Because almost greater size-classes trees in burned plots from Cordón Masle remained standing, it was also possible to record DBH of such dead trees. This situation allowed us to generate a direct estimation on damages to tree density and basal area, by partitioning the Cordón Masle burned plots (CMBP) into two sub-groups, namely: a) Cordón Masle burned plots a (CMBPa), which includes assessments on live and dead trees and b) Cordón Masle burned plots b (CMBPb), where only live trees are considered for such estimations. Regeneration was assessed on each plot by counting the number of seedlings having between 1 and $15 \mathrm{~cm}$ tall.

Vegetation sampling. In the center of each stand, one vegetation subplot of $10 \times 10 \mathrm{~m}$ was delimited in order to record floristic composition. Percent coverage of each vascular plant was recorded by visual estimation. All species were attributed to a particular horizontal layer on recordings, namely: a) stratum 1 of species present in under-story layer ( $0-0.5 \mathrm{~m}$ in height); b) stratum 2 of species present in the low shrub layer $(0.5-1 \mathrm{~m}$ in height); c) stratum 3 of species present in the high shrub layer (1 - $5 \mathrm{~m}$ in height) and d) tree layer (> $5 \mathrm{~m}$ in height). Species not determined in situ were collected for laboratory identification using taxonomical literature (Moore 1982, Matthei 1995, Rodríguez and Quezada 2003). Nomenclature follows to Henríquez et al. (1995) and Domínguez et al. (2006).

Database analyses. Data on stand structure and regeneration were used to elaborate a database for comparisons amongst the groups of plots. We estimated total tree
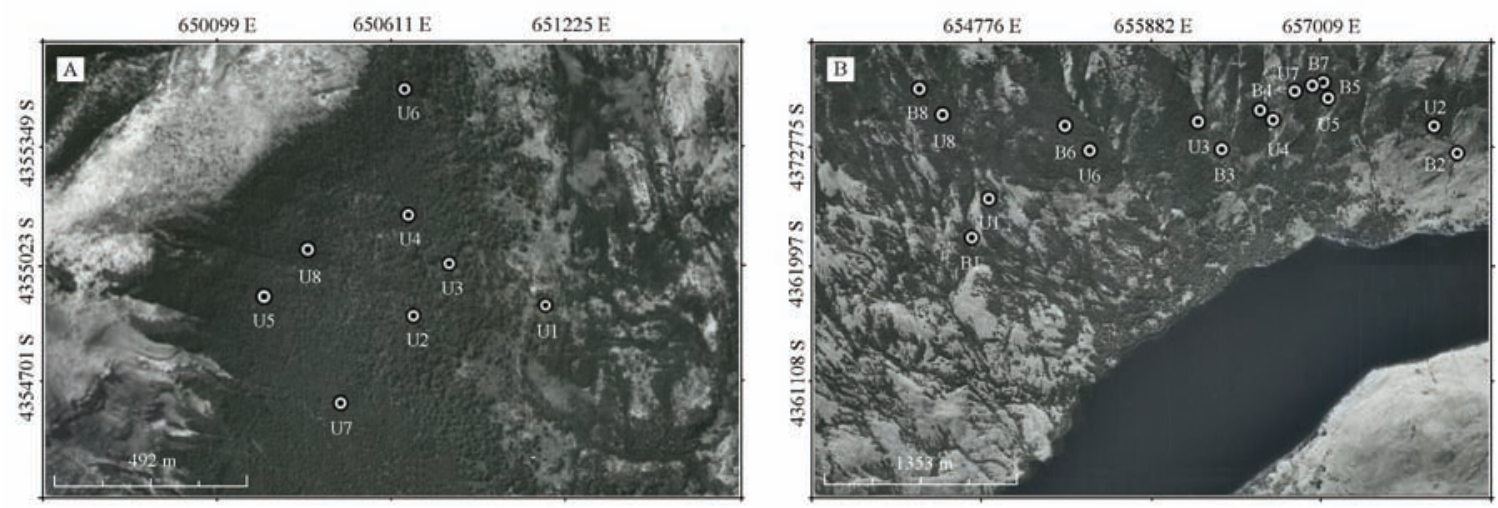

Figure 1. Location of sampling plots at Cerro Paine (A), where the fire perimeter did no affect the area, and at Cordón Masle (B), inside the fire perimeter during the wildfire in $2005(\mathrm{U}=$ unburned, $\mathrm{B}=$ burned).

Localización de las parcelas de muestreo en Cerro Paine (A), donde el perímetro del incendio no afectó el área y en Cordón Masle (B), sector ubicado dentro del perímetro del incendio en el evento del 2005 ( $\mathrm{U}=$ no incendiado, $\mathrm{B}=$ incendiado). 
density (including both live and dead standing trees in burned plots), live standing tree density, tree $\mathrm{DBH}$, total basal area (including both live and dead standing trees in burned plots), live standing basal area and regeneration (saplings and seedlings). Data on floristic composition was used to estimate means and medians for richness and cover of species based on groups of common features among species. The following features were assigned for each species: phytogeographic origin (natives or non-native species) (Matthei 1995, Henríquez et al. 1995, Domínguez et al. 2006), general life forms (trees, tall shrubs, low shrubs, herbs, graminoids, epiphytes) (Donato et al. 2009), and Raunkiaer's plant life forms (phanerophytes, chamaephytes, hemicryptophytes, therophytes, geophytes, epiphytes) (Mueller-Dombois and Ellenberg 1974). In addition, Shannon and Berger Parker indexes were computed for quantifying differences on diversity and taxonomical homogeneity among the groups. These indices were computed from the sum of all absolute covers of individual plant species in each group.

Statistical analyses. Stand structure (tree densities, basal area, dbh, and vegetation layers), regeneration (number of seeds and saplings), plant life forms (general and Raunkiaer's system) and phytogeographic origin (native and exotic plants) were compared among groups using MannWhitney $U$-tests. Statistic significance was accepted at the $0.05 P$ level. Shannon and Berger-Parker indexes were compared by generating confidential intervals from bootstrap estimators (1,000 iterations). Univariate analyses were performed using the PAST software (Hammer et al. 2001).

“Multi-response permutation procedure” (MRPP) using Euclidean was performed to test the hypothesis of no difference in species composition among groups. In this test, an A statistics describes the degree of within-group homogeneity compared to that expected by chance (called effect size) (McCune and Grace 2002). When all entities within groups are identical, $A$ reaches its maximum value $(A=1)$. When the heterogeneity within groups equals the level expected by chance, then $A=0$, and when there is more heterogeneity within groups than the level expected by chance, then $A<0$. In MRPP a $P$ value is given for each test group comparison. Pre-defined groups of plots as described above were used to make multiple comparisons based on species composition data. Following the MRPP, we performed “indicator species analyses” (ISA) (Dufrêne and Legendre 1997) to verify fidelity of species to burned and unburned conditions. These species are responsible for differences between groups in the MRPP. ISA yields an indicator value and a statistical significance for this value from Monte-Carlo randomizations. PC-ORD software (MacCune and Grace 2002) was used for these multivariate analyses.

\section{RESULTS}

Responses on structural attributes. Differences among groups on tree density and basal area were statistically significant. Average densities $( \pm \mathrm{SD})$ of living trees diminished from $545 \pm 251$ trees ha-1 $(\mathrm{CMBPa})$ to $45 \pm 59$ trees ha-1 (CMBPb) (Mann-Whitney $U$-test: $\mathrm{z}=-3.31$, $P<0.001$ ), while the basal area of living trees was reduced from $51.9 \pm 16.9 \mathrm{~m}^{2} \mathrm{ha}^{-1}(\mathrm{CMBPa})$ to $15.1 \pm 13.0 \mathrm{~m}^{2} \mathrm{ha}^{-1}$ (CMBPb) (Mann-Whitney $U$-test: $\mathrm{z}=-3.10, P<0.001$ ). These changes were caused by high fire intensity, which destroyed $91.7 \%$ of the initial tree densities and $70.9 \%$ of the basal area of evaluated stands. Tree mean diameters, however, remained unchanged (figure 2).

Vegetation covers were changed after the fire (table 1).
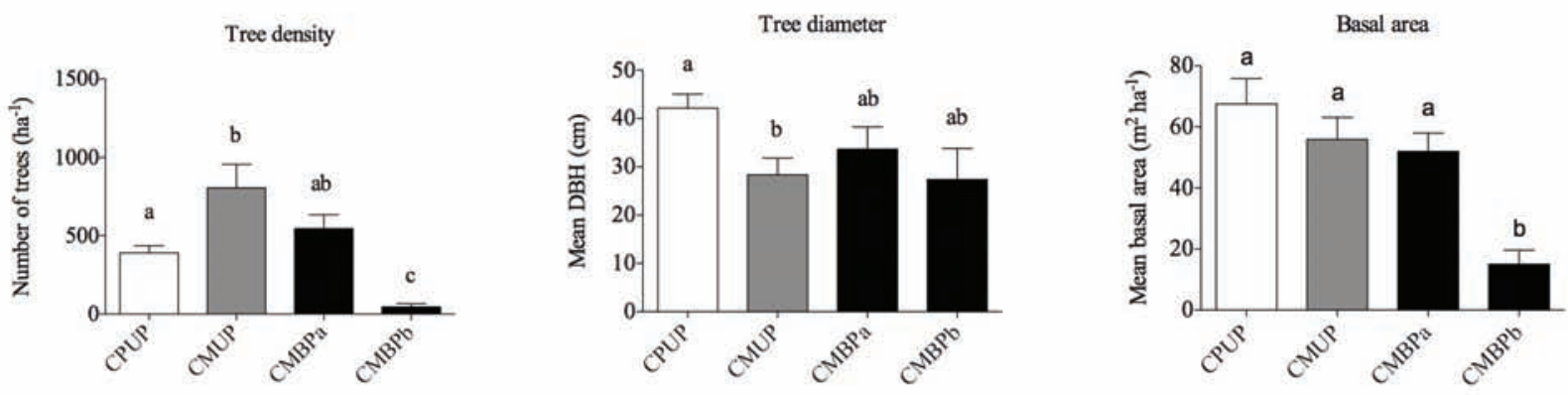

Figure 2. Stand structure features for the group of plots in the present study. CPUP $=$ Cerro Paine unburned plots, CMUP $=$ Cordón Masle unburned plots, $\mathrm{CMBPa}=$ Cordón Masle burned plots live and dead trees and $\mathrm{CMBPb}=$ Cordón Masle burned plots live standing. Means and standard errors are given in each case. Different letters indicate significant differences among groups (Mann-Whitney $U$-test, $95 \%$ ).

Características estructurales para los grupos de parcelas evaluadas en el presente estudio. $\mathrm{CPUP}=$ parcelas no incendiadas del Cerro Paine, $\mathrm{CMUP}=$ parcelas no incendiadas de Cordón Masle, $\mathrm{CMBPa}=$ parcelas incendiadas de Cordón Masle, árboles vivos y muertos y $\mathrm{CMBPb}=$ parcelas incendiadas del Cordón Masle, solo árboles vivos. Los promedios y el error estándar son dados para cada caso. Letras diferentes indican diferencias significativas entre grupos (Mann-Whitney U-test, $95 \%$ ). 
On average, ground vegetation in CMBP reached 96.3 $\pm 45.8 \%$ of relative cover, whereas in CPUP and CMUP this value reached $52.1 \pm 29.4 \%$ and $59.1 \pm 12.7 \%$, respectively (Mann-Whitney $U$-test, $P<0.001$ ). In contrast, tree cover layer reached a reduced value in CMBP of 1.5 $\pm 2.3 \%$, though in CPUP and CMUP this value reached higher values of $37.3 \pm 11.7 \%$ and $43.0 \pm 5.3 \%$, respectively (Mann-Whitney $U$-test, $P<0.001$ ). Shrub layer also shows significant differences among groups. Thus, in CMBP shrub cover reached just $1.9 \pm 2.6 \%$, while in CPUP and CMUP this value reaches $8.2 \pm 9.4 \%$ and 8.6 $\pm 6.4 \%$, respectively (Mann-Whitney $U$-test, $P<0.001$ ) (table 1).

Differences on regeneration patterns were also statistically significant among groups (Mann-Whitney $U$-test, $P<0.001)$. On average $1,125 \pm 1,123$ seedlings ha ${ }^{-1}$ were found in CMBP, while in CPUP and CMUP 23,625 $\pm 24,908$ and $22,750 \pm 16,901$ seedlings ha $^{-1}$ were found, respectively (table 1).

Responses on species composition and diversity. Species composition varied significantly among burned and unburned groups for all species covers (MRPP: $A=0.253$, $\mathrm{T}=-12.397, P<0.001)$. Burned and unburned plot groups differed significantly (pairwise comparisons), but no differences were detected between the CPUP and CMUP (MRPP: $A=0.045, \mathrm{~T}=-1.204, P>0.05$ ). Indicator values computed by ISA showed that from a total of 77 species (appendix 2), 33 can be considered as belonging to burned or unburned conditions, with fidelity values fluctuating from 37.5 (relatively high) to 100 (absolute fidelity in any group). In unburned plot groups, seven species can be considered as belonging to this undisturbed condition (all of them natives) while 26 species are typical for burned condition ( $46 \%$ of them native and $54 \%$ exotic) (figure 3 ).

The richness and cover of species showed also significant differences among groups (Mann-Whitney $U$ test, $P<0.001$ ) (figure 4). The mean number of species $( \pm \mathrm{SD})$ in CMBP was $28.0 \pm 4.8$, while in CPUP and CMUP it reached $17.9 \pm 3.0$ and $12.4 \pm 3.7$ respectively. By dividing this measure between native and exotic species, richness of native ones resulted significantly greater by comparing CPUP and CMUP $16.3 \pm 2.7 \mathrm{v} / \mathrm{s} 11.8 \pm 2.9$ species) (Mann-Whitney $U$-test, $\mathrm{z}=-2.596, P<0.001$ ), while the comparison between CPUP and CMBP and also CMUP and CMBP remained not significant (Mann-Whitney $U$-test, $P>0.05$ ). Exotic species reached significantly higher values in burned plots (Mann-Whitney $U$-test, $P<0.001)$. On average, exotic species richness reached values of $11.9 \pm 4.2$ in CMBP compared with the $1.5 \pm 1.9$ and $0.6 \pm 1.1$ obtained from CPUP and CMUP, respectively (Mann-Whitney $U$-test, $P<0.001$ ). Considering the cover values, no significant changes among the groups were observed (Mann-Whitney $U$-test, $P>0.05$ ). The absolute cover of species in CMBP reached values of $136 \pm$ $46 \%$, while in unburned plots it reached $120 \pm 18 \%$ and

Table 1. Summary of biodiversity indicators for the locations evaluated in the present study. CPUP = Cerro Paine Unburned Plots; CMUP $=$ Cordón Masle Unburned Plots; CMBP $=$ Cordón Masle Burned Plots. Average values and standard deviations are given . Differences among groups of plots are showed (Mann-Whitney $U$-test, $95 \%$ ). For Shannon and Berger-Parker indexes confidence intervals are given from bootstrap estimators and differences among groups are based on Monte-Carlo permutations.

Resumen de indicadores de biodiversidad para las localidades evaluadas en el presente estudio. CPUP = parcelas no incendiadas del Cerro Paine; CMUP = parcelas no incendiadas del Cordón Masle; $\mathrm{CMBP}=$ parcelas incendiadas del Cordón Masle. Se muestran los valores promedios y desviaciones estándar. Se indican las diferencias estadísticas entre los grupos (Mann-Whitney U-test, 95 \%). Para los índices Shannon y Berger-Parker se confeccionaron intervalos de confianza basados en estimadores de tipo bootstrap. Las diferencias entre grupos están basadas en permutaciones Monte-Carlo.

\begin{tabular}{|c|c|c|c|c|c|c|}
\hline \multirow[b]{2}{*}{ Biodiversity indicators } & \multicolumn{3}{|c|}{ Location } & \multicolumn{3}{|c|}{ M-W P } \\
\hline & CPUP & CMUP & СMBP & $\begin{array}{l}\text { CPUP/ } \\
\text { CMUP }\end{array}$ & $\begin{array}{l}\text { CPUP/ } \\
\text { CMBP }\end{array}$ & $\begin{array}{l}\text { CMUP/ } \\
\text { CMBP }\end{array}$ \\
\hline Mean of plant richness & $16.7 \pm 2.9$ & $12.4 \pm 3.7$ & $28 \pm 4.8$ & $* *$ & $* * *$ & $* * *$ \\
\hline Mean of native plants & $15.2 \pm 2.7$ & $11.8 \pm 2.9$ & $16.1 \pm 4.6$ & $* *$ & ns & $* * *$ \\
\hline Mean of exotic plants & $1.5 \pm 1.9$ & $0.6 \pm 1.1$ & $11.9 \pm 4.2$ & ns & $* * *$ & $* * *$ \\
\hline Rate of exotics $(\%)$ & $8.9 \pm 9.6$ & $4.1 \pm 5.9$ & $44.4 \pm 13.3$ & ns & $* * *$ & $* * *$ \\
\hline Absolute vegetation cover $(\%)$ & $120.1 \pm 17.7$ & $146.3 \pm 18.1$ & $135.5 \pm 45.7$ & $* *$ & ns & ns \\
\hline Canopy layer cover relative (\%) & $37.3 \pm 11.7$ & $43.0 \pm 5.3$ & $1.5 \pm 2.3$ & $* * *$ & $* * *$ & $* * *$ \\
\hline Shrub layer cover canopy $(\%)$ & $8.2 \pm 9.4$ & $8.6 \pm 6.4$ & $1.9 \pm 2.6$ & ns & ns & $* *$ \\
\hline Ground layer cover canopy (\%) & $52.1 \pm 29.4$ & $59.1 \pm 12.7$ & $96.3 \pm 45.8$ & ns & $* * *$ & $* * *$ \\
\hline Seedling regeneration $\left(\mathrm{ha}^{-1}\right)$ & $23,625 \pm 24,908$ & $22,750 \pm 16,901$ & $1,125 \pm 1,123$ & ns & $* * *$ & $* * *$ \\
\hline Shannon index & $\begin{array}{c}2.322(\mathrm{CI}= \\
2.211-2.384)\end{array}$ & $\begin{array}{c}1.859(\mathrm{CI}= \\
1.763-1.918)\end{array}$ & $\begin{array}{c}3.212(\mathrm{CI}= \\
3.105-3.254)\end{array}$ & ns & $* * *$ & $* * *$ \\
\hline Berger Parker index & $\begin{array}{c}0.364(\mathrm{CI}= \\
0.333-0.395)\end{array}$ & $\begin{array}{c}0.422(\mathrm{CI}= \\
0.392-0.455)\end{array}$ & $\begin{array}{c}0.161(\mathrm{CI}= \\
0.142-0.182)\end{array}$ & ns & $* * *$ & $* * *$ \\
\hline
\end{tabular}




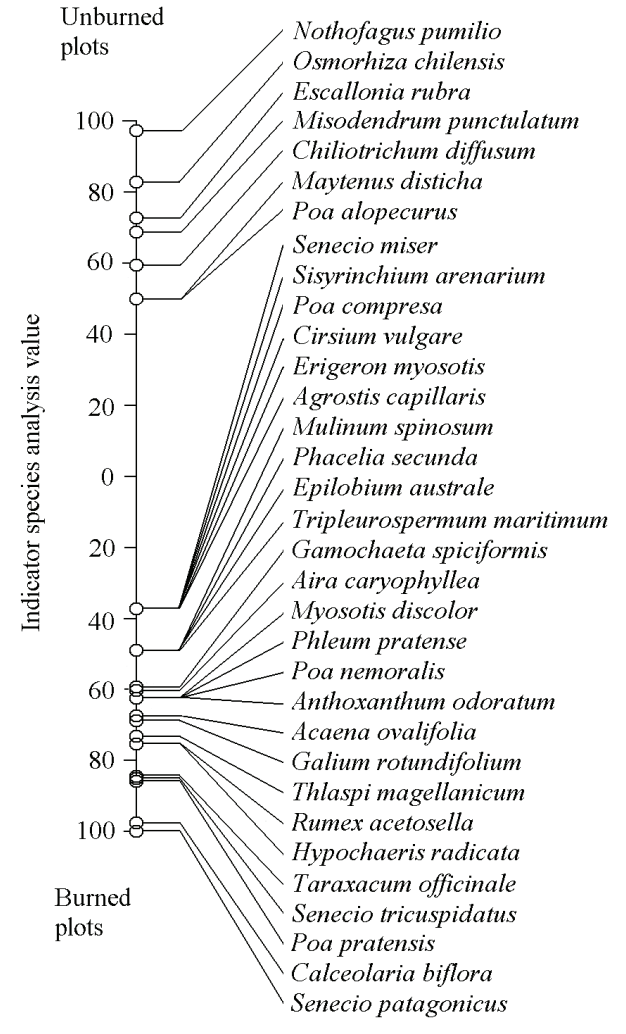

Figure 3. Ordination of species based on indicator species analysis, contrasting association among burned and unburned group of plots. Species are placed according to it's $A$ indicator value.

Ordenación de las especies basada en el análisis de especies indicadoras, contrastando la asociación entre los grupos de parcelas incendiadas y no incendiadas. Las especies son ordenadas de acuerdo al valor indicador $A(P<0,05)$.

$146 \pm 18 \%$ in CPUP and CMUP, respectively. Native species had significantly lower cover values in CMBP $(73 \pm 24 \%)$ than in unburned ones $(110 \pm 16 \%$ and $142 \pm 20 \%$ in CPUP and CMUP, respectively) (MannWhitney $U$-test, $P<0.01$ ). Exotic species however, which were practically absent in CPUP $(10 \pm 13 \%)$ and CMUP $(4 \pm 8 \%)$, reached higher values in CMBP $(62 \pm 33 \%)$ $(P<0.001)$ (figure 4).

Berger-Parker index $(d)$ shows lower values for the CMBP $(d=0.1614, \mathrm{CI}=0.1421-0.1827)$ than those permuted for CPUP $(d=0.3641, \mathrm{CI}=0.333-0.3951)$ and CMUP $(d=0.4227, \mathrm{CI}=0.392-0.4552)$, indicating the reduced cover values of the dominant species ( $N$. pumilio) in burned plots. Shannon index (H') also showed greater values in CMBP $\left(\mathrm{H}^{\prime}=3.212, \mathrm{CI}=3.105-3.254\right)$ than those in CPUP $\left(\mathrm{H}^{\prime}=2.322, \mathrm{CI}=2.211-2.384\right)$ and CMUP $\left(\mathrm{H}^{\prime}=1.859, \mathrm{CI}=1.763-1.918\right)$ showing the incorporation of new species to the disturbed places and relative homogeneity in cover values among them (table 1).
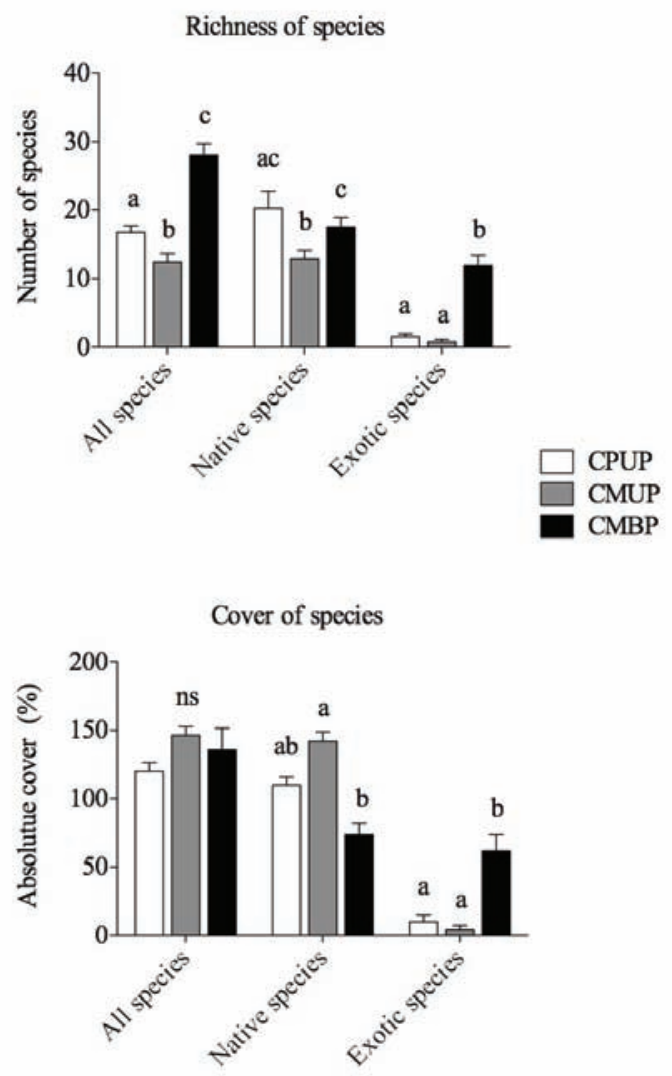

Figure 4. Phytogeographic origin of plant species recorded on this study according to species richness (number of species) and relative covers (\%) in Cerro Paine unburned plots (CPUP), Cordón Masle unburned plots and Cordón Masle burned plots. Means and standard errors are given in each case. Different letters indicate significant differences among groups (Mann-Whitney $U$-test, $95 \%$ ).

Origen fitogeográfico de las especies de plantas registradas en el presente estudio de acuerdo a la riqueza (número de especies) y la cobertura relativa de las mismas (\%) en las parcelas no incendiadas de Cerro Paine (CPUP), parcelas no incendiadas de Cordón Masle (CMUP) y parcelas incendiadas de Cordón Masle (CMBP). Los promedios y el error estándar son dados para cada caso. Letras diferentes indican diferencias significativas entre grupos (Mann-Whitney U-test, $95 \%$ ).

Responses of plant life forms. Both number and cover of phanerophyte and epiphyte species had reduced values in burned plots (figure 5). The damage produced by fire destroyed the components present in the canopy, allowing the incorporation of new understory species to the original ensemble. Average of phanerophyte species $( \pm \mathrm{SD})$ in CMBP reached values of $1.25 \pm 1.4$ compared with the $2.8 \pm 1.2$ and $3.1 \pm 0.6$ species appearing in CPUB and CMUP, respectively. Cover values in CMBP reached $2.5 \pm 3.4 \%$, while in CPUP and CMUP these values reached $46.6 \pm 14.7 \%$ and $48.7 \pm 5.1 \%$, respectively. By contrast, the richness and cover in burned places of both hemicriptophytes and therophytes increased significantly. 


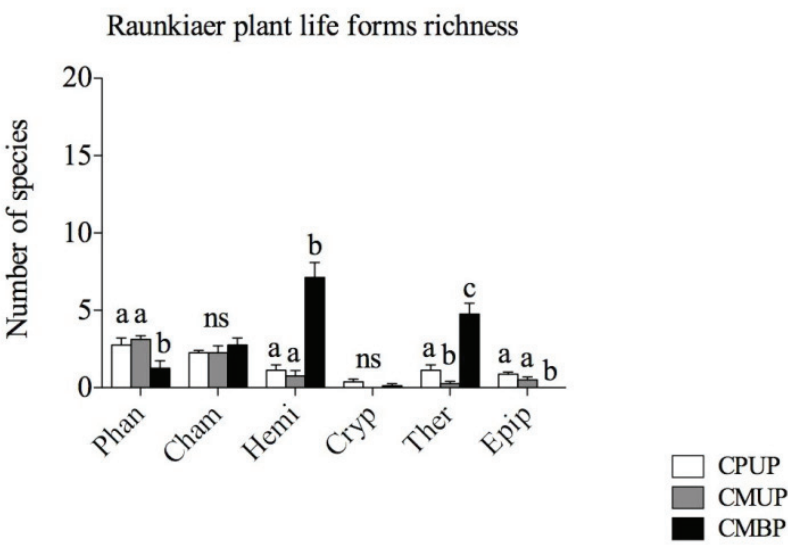

Raunkiaer plant life forms cover

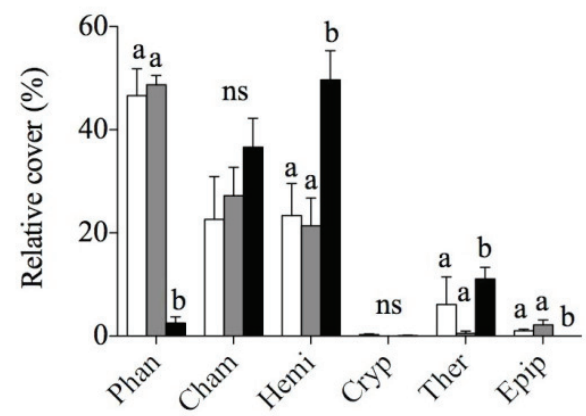

General plant life forms richnes

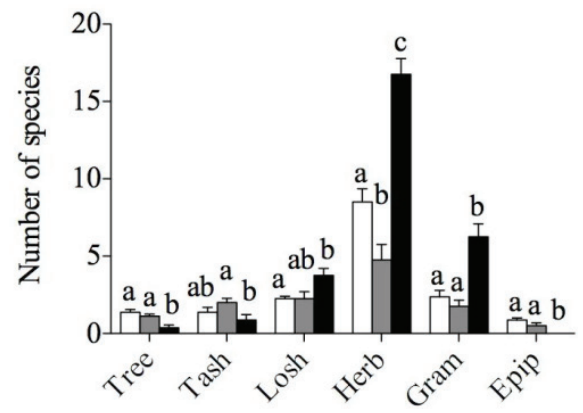

General plant life forms cover

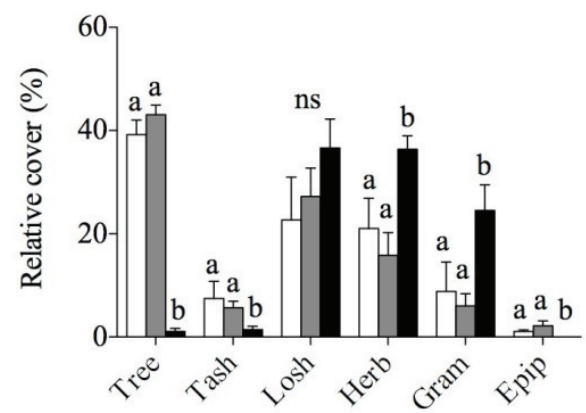

Figure 5. Plant life forms according to species richness (number of species) and relative cover in Cerro Paine unburned plots (CPUP), Cordón Masle unburned plots (CMUP) and Cordón Masle burned plots (CMBP). Means and standard errors are showed. Different letters indicate significant differences among groups (Mann-Whitney $U$-test, 95\%). Raunkiaer plant life forms: PHAN=phanerophytes, $\mathrm{CHAM}=$ chamaephytes, $\mathrm{HEMI}=$ hemicryptophytes, $\mathrm{CRYP}=$ cryptophytes, THER= therophytes, $\mathrm{EPIP}=$ epiphytes. General plant life forms: $\mathrm{TREE}=$ trees, $\mathrm{TASH}=$ tall shrubs, $\mathrm{LOSH}=$ low shrubs, $\mathrm{HERB}=$ herbs, GRAM= graminoids, EPIP= epiphytes.

Formas de vida de las plantas de acuerdo a la riqueza de especies (número de especies) y la cobertura relativa en las parcelas no incendiadas de Cerro Paine (CPUP), parcelas no incendiadas de Cordón Masle (CMUP) y parcelas incendiadas de Cordón Masle. Se muestra la media y el error estándar. Diferentes letras indican diferencias significativas entre grupos (Mann-Whitney U-test, 95 \%). Formas de vida de Raunkiaer: PHAN = fanerófitos, CHAM = caméfitos, HEMI = hemicriptófitos, CRYP = criptófitos, THER = terófitos, EPIP = epifitos. Formas de vida generales de las plantas: TREE $=$ árboles, TASH $=$ arbustos altos, $\mathrm{LOSH}=$ arbustos bajos, $\mathrm{HERB}=$ hierbas, $\mathrm{GRAM}=$ graminoides, $\mathrm{EPIP}=$ epifitos.

Hemicriptophyte species incremented in average from 1.2 \pm 1.0 and $0.7 \pm 1.0$ in CPUP and CMUP to $7.1 \pm 2.7$ in CMBP. Cover incremented from $23.4 \pm 17.6 \%$ and $21.4 \pm$ $15.3 \%$ in CPUP and CMUP respectively to $49.7 \pm 15.9 \%$ in CMBP. Therophyte species average increased from 1.1 \pm 1.0 and $0.2 \pm 0.5$ species (CPUP and CMUP) to $4.7 \pm 2.0$ species in burned plots from Cordón Masle. Covers also increased from $6.1 \pm 15.1 \%$ and $0.5 \pm 1.2 \%$ (CPUP and CMUP) to $11.1 \pm 6.4 \%$ in burned plots (figure 5).

Almost all groups of general plant life forms presented significant differences in comparisons between unburned and burned plots. Tree species diminished on average from $1.3 \pm 0.5$ and $1.1 \pm 0.4$ in CPUP and CMUP to $0.4 \pm 0.5$ in CMBP. Cover changed from $39.2 \pm 7.9 \%$ and $43.5 \pm$ $5.2 \%$ in unburned places (CPUP and CMUP) to $1.1 \pm$ $1.6 \%$ in CMBP. Herbs and graminoids also incremented in burned plots, showing their ability to invade in places where canopy collapsed. Herb species number incremented in average from $8.5 \pm 2.4$ and $4.9 \pm 2.8$ in CPUP and
CMUP, respectively, to $16.7 \pm 2.9$ species in CMBP. Covers of herbs incremented from $20.9 \pm 16.6 \%$ and $15.8 \pm 12.5 \%$ in CPUP and CMUP, respectively, to 36.3 $\pm 7.4 \%$ in CMBP. Graminoid presented also significantly higher values in burned plots. Species numbers in unburned plots reached values of $2.4 \pm 1.2$ and $1.7 \pm 1.2$ (CPUP and CMUP respectively) while in $\mathrm{CMBP}$ this value reached $6.2 \pm 2.4$ species. Cover differences are more notorious, whereas in unburned plots relative cover reached $8.8 \pm$ $16.1 \%$ and $6.0 \pm 6.6 \%$ (CPUP and CMUP respectively), in BPCM this metric reached $24.5 \pm 14.0 \%$ (figure 5).

\section{DISCUSSION}

The increase in total richness recorded in burned plots represents a difficulty for forest recovery. Intensity developed by fire has broken the balance between canopy and understory, providing higher light conditions and bare soil. Thus the incoming of propagules from outside 
sources, like grasslands and shrub-lands communities adjacent to forests (Domínguez et al. 2006), intensifies competition between the new pools of species. Many communities acting as propagule sources are systems which were previously disrupted through fires started by Euro-Chilean settlers (González et al. 2005) until 1950 for livestock production (Martinic 1985, Huber and Markgraf 2003), who simultaneously had introduced exotic species for providing food for livestock. After that, many of these species became naturalized and invaders (sensu Richardson et al. 2000) in many places inside the study area (e.g. Agrostis capillaris L., Poa compresa L., Phleum pratense L.) (Pisano 1974, Domínguez et al. 2006). Species like Holcus lanatus L., Galium aparine L. or Hordeum marinum Hudson remained with relatively low cover and abundance values in undisturbed forest, but became more abundant in burned places. Since biological invasions are assumed as a potential risk for biodiversity conservation in protected areas (e.g. Mack et al. 2000), more local and detailed studies focused on taxonomical and ecological attributes of exotic and invasive species are required, in order to determine priority management decisions looking for diminishing present impact of infested areas and control of new focus of invasion (Domínguez et al. 2006).

Structural changes of stratification layering involve deep modifications on forest dynamics, seriously limiting recruitment and establishment of new tree populations. Although a small amount of seedlings was detected in burned areas, we speculate that seedling emergence and survival will be strongly affected by the structural changes affecting the forest stands. As showed by experimental studies, $N$. pumilio seedling survival on more canopy burned places is strongly limited by synergic effects from loss of soil organic matter, incoming radiation (Kitzberger et al. 2005) and drying effects of strong winds (Veblen et al. 1996) affecting soil water retention. In addition, strongly burned soils are usually nitrogen deficient because of volatilization of organic compounds and degradation of humus layer (Certini 2005). Since $N$. pumilio appears to be a species of higher nitrogen requirement in the study area (Armesto et al. 1992), establishment of new population on high burned areas seems unlikely. In addition, no vegetative reproduction was observed from burned trees, making the resilience of forest a process highly dependent from naturally established seedlings. Nevertheless, forest borders adjacent to unburned stands would act as buffer areas, providing intermediate soil biochemical conditions, semi-shade levels of luminosity, and higher number of seeds from unburned forest boundaries, where recruitment would be most successful. As showed by Fajardo and McIntire (2010), burned forests edges exhibit aggregate establishment of trees that tend to merge producing an “extremely unusual aggregation of mature trees”. In this sense, a mast-seeding interval would completely change the recruitment conditions observed in this study and consequently, the recovery state of the affected stands. Efforts to restore burned forests should focus on forest edges.

Changes on plant life forms is another forest attribute greatly affected after the fire. Trees and phanerophytes were severely reduced to the benefit of under-story species, like small shrubs, herbs and graminoids (low phanerophytes, hemicryptophytes and therophytes), which is a typical pattern for disrupted ecosystems where gaps and higher light conditions favored annual or short-lived perennials (Rusch et al. 2003). Species of lower statures presenting rapid responses in growth, reproduction and short life cycles are able to develop in disturbed sites, invade new communities and alter successional pathways (Donato et al. 2009). In addition, the disappearing of trees as key structures on ecosystems would be a critical factor on the survival of dependent species as bird assemblages; making them inhospitable for food acquisition or refuge from predators (Díaz et al. 2005). The notorious presence of Senecio patagonicus Hook. et Arn., a native species in cover replacing previously abundant ones Escallonia rubra (Ruiz et Pavon) Pers. and Maytenus disticha (Hook.f.) Urban, can contribute also in turn to the successional rates and pathways, as seems to be the situation in disrupted N. pumilio places in Nahuel Huapi National Park, Argentina (Kitzberger et al. 2005).

\section{CONCLUDING REMARKS}

This study addresses the ecological significance produced by the last huge fire, which occurred in Torres del Paine Biosphere Reserve by showing the impact of fire on forest biodiversity components. Collapse of canopy, higher rates of exotic species in burned places and poor tree regeneration in burned places were detected. Such changes destroy the resilience capacity of forests by conducting a dominance shift towards a mixed assemblage dominated by re-sprouting shrub-lands and exotic herbs, making restoration efforts highly unsuccessful. Since fire severity was high, we cannot set limits for the resilience thresholds. Thus we suggest focusing future research on forest borders, which, due to their intermediate biophysical conditions, would act as more suitable places in restoration programs.

The difficulty to set long term restoring programs lies not only in the high intensity developed during the last event, but also on the high frequency recorded in fire events which occurred as a consequence of human ignitions in recent years. During the last 24 years, 29 human-ignited fires destroyed approximately 30,000 ha in the reserve boundaries. Fire protection is needed throughout, and so are adequate training and equipment against fire events for rangers. Furthermore, tourists must be informed of the consequences of fire on biodiversity, and, on the field, more rangers must be present to oversee the conduct of campers, who represent the highest risk segment. 
Until now management plans have lacked monitoring information (e.g. biodiversity indicators), which can show the ecological integrity of the ecosystems, as well as reveal unwanted changes on biodiversity attributes. In this way, disturbances derived from human influences are not detected and not recorded, and the management decisions are not taken from scientific information. There is a need for quantifiable information to be added to management plans, like biodiversity indicators for long term monitoring programs. Such information can help managers take decisions related to conditions which they wish to maintain and conserve for the future.

\section{ACKNOWLEDGEMENTS}

The Asociación Medio Ambiental Torres del Paine provided the field support. Thanks to Juliana Torres for logistic coordination in the field. The Corporación Nacional Forestal (CONAF) provided authorization for research in the area. Thanks to Juan Toro, ranger in Laguna Azul, for his field help. The first author thanks the National Commission on Science and Technology (CONICYT) and the German Academic Exchange Service (DAAD) for funding his $\mathrm{PhD}$ scholarship at the Albert Ludwig University of Freiburg, Germany.

\section{REFERENCES}

Amigo J, C Ramírez. 1998. A bioclimatic classification of Chile: woodland communities in the temperate zone. Plant Ecology 136: 9-26.

Armesto JJ, I Casassa, O Dollenz. 1992. Age structure and dynamics of Patagonian beech forests in Torres del Paine National Park, Chile. Vegetatio 98: 13-22.

Certini G. 2005. Effects of fire on properties of forest soil: a review. Oecologia 143: 1-10.

Cole DN, PB Landres. 1996. Threats to wilderness ecosystems: Impacts and research needs. Ecological Applications 6 (1): 168-184.

CONAF (Corporación Nacional Forestal, CL). 2007. Plan de manejo del Parque Nacional Torres del Paine. 230 p.

Díaz IA, JJ Armesto, S Reid, KE Sieving, MF Willson. 2005. Linking forest structure and composition: avian diversity in successional forests of Chiloé island, Chile. Biological Conservation 123: 91-101.

Domínguez E, A Elvebakk, C Marticorena, A Pauchard. 2006. Plantas introducidas en el Parque Nacional Torres del Paine, Chile. Gayana Botanica 63: 131-141.

Donato DC, JB Fontaine, WD Robinson, JB Kauffman, EL Law. 2009. Vegetation response to a short interval between highseverity wildfires in a mixed-evergreen forest. Journal of Ecology 97: 142-154.

Dufrêne M, P Legendre. 1997. Species assemblages and indicator species: the need for a flexible asymmetrical approach. Ecological Monographs 67: 345-366.

Fajardo A, EJB McIntire. 2010. Merged trees in second-growth, fire origin forest in Patagonia, Chile: positive spatial association patterns and their ecological implications.
American Journal of Botany 97(9): 1424-1430.

Freeman JP, TJ Stohlgren, ME Hunter, PN Omi, EJ Martinson, GW Chong, CS Brown. 2007. Rapid assessment of post fire plant invasions in coniferous forests of the western United States. Ecological Applications 17: 1656-1665.

González ME, TT Veblen, JS Sibold. 2005. Fire history of Araucaria-Nothofagus forests in Villarrica National Park, Chile. Journal of Biogeography 32: 1187-1202.

Hammer O, DAT Harper, PD Ryan. 2001. PAST: Paleontological statistical software package for education and data analysis. Palaeontología electrónica 4: 1-9.

Henríquez J, E Pisano, C Marticorena. 1995. Catálogo de la flora vascular de Magallanes (XII Región), Chile. Anales del Instituto de la Patagonia 23: 5-30.

Hindelbrand-Vogel R, R Godoy, A Vogel. 1990. SubantarticAndean Nothofagus pumilio forests. Vegetatio 89: 55-68.

Huber UM, V Markgraf. 2003. European impact on fire regimes and vegetation dynamics at the steppe-forest ecotone of southern Patagonia. The Holocene 13: 567-579.

Kitzberger T, E Raffaele, K Heinemann, MJ Mazzarino. 2005. Effect of fire severity in a north Patagonian subalpine forest. Journal of Vegetation Science 16: 5-12.

Mack RN, D. Simberloff, WM Lonsdale, MC Evans, M Clout, FA Bazzaz. 2000. Biotic invasions: causes, epidemiology, global consequences, and control. Ecological Applications 10: 689-710.

Martinic MB. 1985. La ocupación y el impacto del hombre sobre el territorio. In Boelcke O, DM Moore, FA Roig eds. Transecta botánica de la Patagonia austral. Buenos Aires, Argentina. p. 95-104.

Matthei O. 1995. Manual de las malezas que crecen en Chile. Santiago, Chile. Alfabeta Impresiones. 545 p.

McCune B, JB Grace. 2002. Analysis of ecological communities. Oregon, USA. MJM Software Design. 300 p.

Moore D. 1982. Flora of Tierra del Fuego. Shrosphire, England. Anthony Nelson. Missouri, USA. Missouri Botanical Garden. 396 p.

Mueller-Dombois D, H Ellenberg. 1974. Aims and methods of vegetation ecology. New York, USA. John Wiley and Sons. $574 \mathrm{p}$.

Navarro-Cerrillo RM, A Hayas, A García-Ferrer, R HernándezClemente, P Duhalde, L González. 2008. Caracterización de la situación post-incendio de 2005 en el Parque Nacional Torres del Paine (Chile) a partir de imágenes multiespectrales. Revista Chilena de Historia Natural 81: 95-110.

Noss RF. 1990. Indicators for biodiversity monitoring: a hierarchical approach. Conservation Biology 4: 355-364.

Pauchard A, P Villarroel. 2002. Protected areas in Chile: History, current status and challenges. Natural Areas Journal 22: 318-330.

Pisano E. 1974. Estudios ecológicos de la región continental sur del área andino-patagónico II. Contribución a la fitogeografía de la zona del Parque Nacional Torres del Paine. Anales del Instituto de la Patagonia 5: 59-104.

Richardson D, P Pysek, M Rejmánek, MG Barbour, FD Panetta, CJ West. 2000. Naturalization and invasion of alien plants: concepts and definitions. Diversity and Distributions 6: 93107.

Rodríguez R, M Quezada. 2003. Fagaceae. In Marticorena C, R Rodríguez eds. Flora de Chile. Concepción, Chile. 
Universidad de Concepción. p 64-78.

Rusch GM, JG Pausas, J Leps. 2003. Plant functional types in relation to disturbance and land use: Introduction. Journal of Vegetation Science 14: 307-310.

Veblen TT, V Markgraf. 1988. Steppe expansion in Patagonia? Quaternary research 30: 331-338.

Veblen TT, M Mermoz, C Martin, E Ramilo. 1989. Effect of exotic deer on forest regeneration and composition in Northern Patagonia. Journal of Applied Ecology 26: 711-724.
Veblen TT, C Donoso, T Kitzberger, A Rebertus. 1996. Ecology of southern Chilean and Argentinean Nothofagus forests. In Veblen TT, R Hill, J Read eds. The ecology and biogeography of Nothofagus forests. New Haven and London. Yale University Press. p. 293-353.

Veblen TT, T Kitzberger, E Raffaele, M Mermoz, ME González, JS Sibold, A Holz. 2008. The historical range of variability of fires in the Andean-Patagonian Nothofagus forest region. International Journal of Wildland Fire 17: 724-741.

Recibido: 25.06.10

Aceptado: 07.01.11 
Appendix 1. Summary of site conditions for the stand plots evaluated in the present study (soil texture: $\mathrm{sL}=\mathrm{sandy}$ loam; $\mathrm{L}=\mathrm{loam}$ ). Resumen de condiciones de sitio para las parcelas evaluadas en el presente estudio (textura del suelo: $\mathrm{sL}=$ franco arenoso; $\mathrm{L}=$ franco).

\begin{tabular}{|c|c|c|c|c|c|c|c|c|}
\hline Stand plot / replicate & 1 & 2 & 3 & 4 & 5 & 6 & 7 & 8 \\
\hline \multicolumn{9}{|c|}{ Cerro Paine unburned plots } \\
\hline Latitude & 651089 & 650737 & 650774 & 650650 & 650218 & 650657 & 650411 & 650348 \\
\hline Longitude & 4354797 & 4354725 & 4354998 & 4355157 & 4354924 & 4355561 & 4354571 & 4355055 \\
\hline Elevation (m) & 356 & 450 & 453 & 498 & 674 & 531 & 545 & 652 \\
\hline Aspect $\left({ }^{\circ}\right)$ & $\mathrm{E}$ & SE & SE & SE & SE & E & SE & SE \\
\hline Inclination $\left(^{\circ}\right)$ & 10 & 20 & 9 & 29 & 10 & 5 & 20 & 25 \\
\hline Soil texture & sL & $\mathrm{L}$ & sL & $\mathrm{L}$ & $\mathrm{L}$ & $\mathrm{L}$ & $\mathrm{L}$ & $\mathrm{L}$ \\
\hline Herbivory index & 1 & 0 & 0 & 0 & 0 & 0 & 0 & 0 \\
\hline \multicolumn{9}{|c|}{ Cordón Masle unburned plots } \\
\hline Latitude & 654620 & 658025 & 656212 & 656646 & 657123 & 655459 & 656882 & 654483 \\
\hline Longitude & 4362219 & 4362741 & 4362807 & 4362871 & 4362937 & 4362649 & 4362992 & 4362924 \\
\hline Elevation (m) & 430 & 433 & 464 & 499 & 492 & 557 & 530 & 612 \\
\hline Aspect $\left({ }^{\circ}\right)$ & S & SE & SE & $\mathrm{SE}$ & SE & $\mathrm{S}$ & SE & SE \\
\hline Inclination $\left({ }^{\circ}\right)$ & 3 & 6 & 27 & 22 & 20 & 23 & 35 & 5 \\
\hline Soil texture & sL & sL & $\mathrm{L}$ & $\mathrm{sL}$ & sL & $\mathrm{sL}$ & sL & $\mathrm{L}$ \\
\hline Herbivory index & 0 & 0 & 0 & 0 & 0 & 0 & 0 & 0 \\
\hline \multicolumn{9}{|c|}{ Cordón Masle burned plots } \\
\hline Latitude & 654571 & 658049 & 656369 & 656734 & 657082 & 655308 & 657006 & 654347 \\
\hline Longitude & 4362102 & 4362543 & 4362626 & 4362822 & 4363046 & 4362803 & 4363022 & 4363099 \\
\hline Elevation (m) & 405 & 381 & 527 & 464 & 526 & 598 & 538 & 638 \\
\hline Aspect $\left({ }^{\circ}\right)$ & S & $\mathrm{SE}$ & $\mathrm{NE}$ & $\mathrm{SE}$ & $\mathrm{SE}$ & $\mathrm{SE}$ & $\mathrm{SE}$ & $\mathrm{SE}$ \\
\hline Inclination $\left(^{\circ}\right)$ & 5 & 15 & 25 & 22 & 26 & 20 & 32 & 9 \\
\hline Soil texture & sL & sL & $\mathrm{L}$ & $\mathrm{sL}$ & sL & $\mathrm{sL}$ & sL & $\mathrm{sL}$ \\
\hline Herbivory index & 0 & 0 & 0 & 0 & 0 & 0 & 0 & 0 \\
\hline
\end{tabular}


Appendix 2. List of species appearing on vegetation plots. Species are arranged alphabetically. Family codes (Fam) are formed by initial letters of the family name. The following information is given for each species: general plant life forms (GLF): Tree $=$ trees, $\mathrm{Tshr}=$ tall shrub, Lshr = low shrubs, Herb = herbs, Gram = graminoids, Epip = epiphytes; Raunkiaer plant life forms (RLF): Phan $=$ phanerophytes, Cham = chamaephytes, Epip = epiphytes, Geop= geophytes (Cryptophytes), Hemi $=$ hemicryptophytes, Thero $=$ therophytes; Phytogeographic origin $(\mathrm{O})$ : $\mathrm{E}=$ exotic (non-native); $\mathrm{N}=$ native; frequency of species in Cerro Paine unburned plots (CPUP), Cordón Masle unburned plots (CMUP) and Cordón Masle burned plots (CMBP).

Listado de especies registradas en los censos de vegetación. Las especies están ordenadas alfabéticamente. Los códigos de las familias (Fam) están formados por las letras iniciales de los nombres de las familias. La siguiente información es dada para cada especie: Formas de vida generales $(\mathrm{GLF})$ : Tree $=$ árboles, $\mathrm{Tshr}=$ arbustos altos, $\mathrm{Lshr}=$ arbustos bajos, Herb $=$ hierbas, Gram $=$ graminoides, Epip $=$ epifitos; Formas de vida de Raunkiaer (RLF): Phan = fanerófitos, Cham = caméfitos, Hemi = hemicriptófitos, Geop = geófitos (criptófitos), Ther = terófitos, Epip = epifitos; Origen fitogeográfico (O): $\mathrm{E}$ = exóticas, $\mathrm{N}$ = nativas; Frecuencia de las especies en las parcelas no incendiadas de Cerro Paine (CPUP), parcelas no incendiadas de Cordón Masle (CMUP) y las parcelas incendiadas de Cordón Masle (CMBP).

\begin{tabular}{|c|c|c|c|c|c|c|c|}
\hline Species & Fam & GLF & RLF & $\mathrm{O}$ & CPUP & CMUP & CMBP \\
\hline Acaena ovalifolia Ruiz et Pavón & Ros & Herb & Hemi & $\mathrm{N}$ & 62.5 & 12.5 & 75.0 \\
\hline Acaena pinnatifida Ruiz et Pavón & Ros & Herb & Hemi & $\mathrm{N}$ & 25.0 & 12.5 & 62.5 \\
\hline Agrostis capillaris L. & Poa & Gram & Ther & $\mathrm{E}$ & - & - & 37.5 \\
\hline Aira caryophyllea L. & Poa & Gram & Ther & $\mathrm{E}$ & 12.5 & - & 62.5 \\
\hline Anemone multifida Poiret & Ran & Herb & Hemi & $\mathrm{N}$ & - & - & 25.0 \\
\hline Anthoxanthum odoratum L. & Poa & Gram & Ther & $\mathrm{E}$ & - & - & 62.5 \\
\hline Arachnithis quetrihuensis Dimitri & Cor & Herb & Geop & $\mathrm{N}$ & 37.5 & - & 12.5 \\
\hline Baccharis magellanica (Lam.) Pers & Ast & Lshr & Cham & $\mathrm{N}$ & 12.5 & - & 37.5 \\
\hline Berberis microphylla G. Forster & Ber & Tshr & Phan & $\mathrm{N}$ & 37.5 & 75.0 & 62.5 \\
\hline Blechnum penna-marina (Poiret) Kuhn & Ble & Herb & Hemi & $\mathrm{N}$ & 37.5 & 25.0 & - \\
\hline Calceolaria biflora Lam. & Scr & Herb & Hemi & $\mathrm{N}$ & 37.5 & 12.5 & 100.0 \\
\hline Calceolaria uniflora Lam. & Scr & Herb & Hemi & $\mathrm{N}$ & 12.5 & - & - \\
\hline Cerastium arvense L. & Car & Herb & Hemi & $\mathrm{E}$ & - & - & 12.5 \\
\hline Chiliotrichum diffusum (G. Forster) Kuntze & Ast & Tshr & Phan & $\mathrm{N}$ & 50.0 & 75.0 & 12.5 \\
\hline Chloraea magellanica Hook. f. & Orc & Herb & Hemi & $\mathrm{N}$ & 37.5 & 12.5 & - \\
\hline Cirsium vulgare (Savi) Ten. & Ast & Herb & Ther & $\mathrm{E}$ & - & - & 37.5 \\
\hline Cyptopteris fragilis (L.) & Woo & Herb & Hemi & $\mathrm{N}$ & - & 25.0 & - \\
\hline Dactilys glomerata L. & Poa & Gram & Hemi & $\mathrm{E}$ & - & - & 25.0 \\
\hline Deschampsia flexuosa (L.) Trin. & Poa & Gram & Hemi & $\mathrm{E}$ & 100.0 & 100.0 & 62.5 \\
\hline Embothrium coccineum J. R. et G. Forster & Pro & Tree & Phan & $\mathrm{N}$ & 12.5 & - & - \\
\hline Empetrum rubrum Vahl ex Willd. & Emp & Lshr & Cham & $\mathrm{N}$ & - & - & 12.5 \\
\hline Epilobium australe Poepp. et Hausskn & Ona & Herb & Hemi & $\mathrm{N}$ & - & - & 50.0 \\
\hline Erigeron myosotis Pers. & Ast & Herb & Hemi & $\mathrm{N}$ & - & - & 37.5 \\
\hline Erodium cicutarium (L.) L'Hér. ex Aiton & Ger & Herb & Hemi & $\mathrm{N}$ & - & - & 25.0 \\
\hline Escallonia rubra (Ruiz et Pavón) Pers. & Sax & Lshr & Cham & $\mathrm{N}$ & 62.5 & 100.0 & 37.5 \\
\hline Galium aparine L. & Rub & Herb & Hemi & $\mathrm{E}$ & 37.5 & 12.5 & 62.5 \\
\hline Galium rotundifolium $\mathrm{L}$. & Rub & Herb & Hemi & $\mathrm{E}$ & 50.0 & 12.5 & 75.0 \\
\hline Gamochaeta nivalis Cabr. & Ast & Herb & Hemi & $\mathrm{N}$ & - & - & 25.0 \\
\hline Gamochaeta spiciformis (Sch. Bip) Cab. & Ast & Herb & Hemi & $\mathrm{N}$ & 12.5 & - & 62.5 \\
\hline Gaultheria mucronata (L. f.) Hook. et Arn. & Eri & Lshr & Cham & $\mathrm{N}$ & 37.5 & 12.5 & - \\
\hline Gavilea lutea (Pers.) M. N. Correa & Orc & Herb & Hemi & $\mathrm{N}$ & 62.5 & 12.5 & - \\
\hline Geranium magellanicum Hook. f. & Ger & Herb & Hemi & $\mathrm{N}$ & - & - & 25.0 \\
\hline Geum magellanicum Pers. & Ros & Herb & Hemi & $\mathrm{N}$ & 12.5 & 12.5 & 12.5 \\
\hline Hieracium antarcticum Durv. & Ast & Herb & Hemi & $\mathrm{N}$ & 37.5 & 12.5 & 12.5 \\
\hline Holcus lanatus L. & Poa & Gram & Ther & $\mathrm{E}$ & 25.0 & - & 75.0 \\
\hline Hordeum marinum Hudson & Poa & Gram & Hemi & $\mathrm{E}$ & - & 12.5 & 12.5 \\
\hline Hypochaeris radicata $\mathrm{L}$. & Com & Herb & Hemi & $\mathrm{E}$ & - & - & 75.0 \\
\hline
\end{tabular}


Continuation of previous table.

\begin{tabular}{|c|c|c|c|c|c|c|c|}
\hline Junellia odonelli Mold. & Ver & Herb & Hemi & $\mathrm{N}$ & - & - & 12.5 \\
\hline Lathyrus nervosus Lam. & Pap & Herb & Hemi & $\mathrm{N}$ & 62.5 & 12.5 & 62.5 \\
\hline Leucheria hahnii Franchet & Ast & Herb & Hemi & $\mathrm{N}$ & - & - & 25.0 \\
\hline Loasa bergii Hieron & Loa & Herb & Hemi & $\mathrm{N}$ & - & - & 12.5 \\
\hline Lolium perenne L. & Poa & Gram & Hemi & $\mathrm{E}$ & - & - & 25.0 \\
\hline Luzula alopecurus Desv. & Jun & Herb & Hemi & $\mathrm{N}$ & - & 12.5 & 25.0 \\
\hline Maytenus disticha (Hook. f.) Urban & Cel & Lshr & Cham & $\mathrm{N}$ & 62.5 & 37.5 & - \\
\hline Maytenus magellanica (Lam.) Hook. f. & Cel & Tree & Phan & $\mathrm{N}$ & 25.0 & 12.5 & - \\
\hline Missodendrum punctulatum Banks ex DC. & Mis & Epip & Epip & $\mathrm{N}$ & 87.5 & 50.0 & - \\
\hline Mulinum spinosum (Cav.) Pers. & Api & Tshr & Cham & $\mathrm{N}$ & - & - & 37.5 \\
\hline Myoschilos oblongum Ruiz et Pavón & San & Tshr & Phan & $\mathrm{N}$ & 50.0 & 50.0 & 12.5 \\
\hline Myosotis arvensis (L.) Hill & Bor & Herb & Ther & $\mathrm{E}$ & - & - & 25.0 \\
\hline Myosotis discolor Pers. & Bor & Herb & Ther & $\mathrm{E}$ & - & - & 62.5 \\
\hline Nothofagus pumilio (Poepp. et Endl.) Krasser & Not & Tree & Phan & $\mathrm{N}$ & 100.0 & 100.0 & 37.5 \\
\hline Oreomyrris hookeri Mathias et Constance & Api & Herb & Hemi & $\mathrm{N}$ & - & - & 12.5 \\
\hline Osmorhiza chilensis Hook. et Arn. & Api & Herb & Hemi & $\mathrm{N}$ & 100.0 & 100.0 & - \\
\hline Perezia recurvata (Vahl) Less. & Ast & Herb & Hemi & $\mathrm{N}$ & 12.5 & - & - \\
\hline Phacelia secunda J. F. Gmel & Hyd & Herb & Hemi & $\mathrm{N}$ & - & - & 50.0 \\
\hline Phleum alpinum L. & Poa & Gram & Hemi & $\mathrm{N}$ & 12.5 & 25.0 & - \\
\hline Phleum pratense L. & Poa & Gram & Hemi & $\mathrm{E}$ & - & - & 62.5 \\
\hline Poa alopecurus (Gaudich.) Kunth & Poa & Gram & Ther & $\mathrm{N}$ & 75.0 & 25.0 & - \\
\hline Poa annua L. & Poa & Gram & Ther & $\mathrm{E}$ & - & - & 12.5 \\
\hline Poa compressa L. & Poa & Gram & Ther & $\mathrm{E}$ & - & - & 37.5 \\
\hline Poa nemoralis L. & Poa & Gram & Ther & $\mathrm{E}$ & - & - & 62.5 \\
\hline Poa pratensis L. & Poa & Gram & Hemi & $\mathrm{N}$ & 12.5 & 12.5 & 87.5 \\
\hline Ribes cucculatum Hook. et Arn. & Sax & Lshr & Cham & $\mathrm{N}$ & 12.5 & 25.0 & 12.5 \\
\hline Rubus geoides Sm. & Ros & Herb & Hemi & $\mathrm{N}$ & 12.5 & - & - \\
\hline Rumex acetosella L. & Pol & Herb & Hemi & $\mathrm{E}$ & - & - & 75.0 \\
\hline Senecio bracteolatus Hook. et Arn. & Ast & Herb & Cham & $\mathrm{N}$ & 25.0 & 12.5 & 12.5 \\
\hline Senecio miser Hook. f. & Ast & Herb & Cham & $\mathrm{N}$ & - & - & 37.5 \\
\hline Senecio patagonicus Hook. et Arn. & Ast & Lshr & Cham & $\mathrm{N}$ & - & - & 100.0 \\
\hline Senecio tricuspidatus Hook. et Arn. & Ast & Lshr & Cham & $\mathrm{N}$ & 12.5 & 37.5 & 87.5 \\
\hline Sisyrinchium arenarium Poepp. & Iri & Herb & Hemi & $\mathrm{N}$ & - & - & 37.5 \\
\hline Taraxacum officinale Weber ex F. H. Wigg. & Ast & Herb & Hemi & $\mathrm{E}$ & - & 12.5 & 87.5 \\
\hline Thlaspi magellanicum Comm. ex Poiret & Cru & Herb & Hemi & $\mathrm{N}$ & 50.0 & 25.0 & 100.0 \\
\hline Trifolium repens L. & Pap & Herb & Hemi & $\mathrm{E}$ & 12.5 & - & 50.0 \\
\hline Tripleurospermum maritimum (L.) W. D. J. Koch & Ast & Herb & Hemi & $\mathrm{E}$ & - & 12.5 & 37.5 \\
\hline Valeriana carnosa Sm. & Val & Herb & Hemi & $\mathrm{N}$ & - & - & 25.0 \\
\hline Vicia magellanica Hook. f. & Pap & Herb & Hemi & $\mathrm{N}$ & 37.5 & 37.5 & 50.0 \\
\hline Viola maculata Cav. & Vio & Herb & Hemi & $\mathrm{N}$ & 100.0 & 100.0 & 87.5 \\
\hline
\end{tabular}

